\title{
Analysis of the Population Characteristics of Peasant Household and Health Investment in Poor Areas
}

\author{
Hong-Xia LU \\ School of Management, Wuhan Donghu University, Wuhan, 430212, China. \\ Hongxia189@163.com
}

Keywords: Peasant household, Population characteristics, Health investment.

\begin{abstract}
By using the survey data collected in the process of investigating the situation for the old peasant households in the county below the national poverty line, the author analyzes health investment level of the peasant household with different domestic population characteristics in XiaoChang and HongAn county of Hubei province, therefore finds out that the impact of family sex ratio to the farmers health investment is not significant , also knows that the family population scale and family population burden have significant influence on the farmers health investment level, the overall health investment level of all the households has been continuously promoted with the population expansion , but households' per capita health investment level remarkable shows the opposite trend. The author concludes that The health investment level of family is being significantly raised with the generation number increased and the level for the households which burdens less is the highest and that of the pure labor family or farmers is the least. Finally, several relevant resolutions and suggestions can be read in the following.
\end{abstract}

\section{Introduction}

Health investment refers to prevent diseases, cure, recovery, and develop the basic and the most common people's social activities, labor production capacity, and consumption of economic resources ( Hongbo CHEN, Keli WANG, 2007). Many factors affect health investment, such as health needs, population characteristics, medical price, income level, etc. The population characteristic is one of the important factors. The individual level is mainly a population of gender, age, whether laborer or not, etc. Family level mainly refers to the family population scale, the sex ratio, family structure, etc. At present, more research of health investment under different demographic in the personal level is done, but neither is the research which is from domestic population characteristics to investigate health investment. This paper will analysis object in the view of peasant household to investigate formation characteristics of family population to the impact of health investment from perspective of population economics, consumer behavior.

\section{Resource of Data and Study Design}

\section{Resource of Data}

Research data comes from large peasant household survey of the 2014 national group in povertystricken XiaoChang and HongAn county of Hubei province. We investigated 3 towns which were randomly chosen from those countries. In every town, we picked 100 families in 10 villages each in three towns randomly and equidistantly. Survey include collected 2014 farmer family finances, family members basic population information, family members detailed health (including two weeks sicken and serious illness) and farmers on the medical security project related aspects of cognitive and using information. According to the research content, this paper uses some part of the survey material, including 6077 sample peasant households and 26350 sample population. 


\section{Study Design}

Health care spending is the main index to measure health outcome. The paper employed the family health outcome in 2014 as a index, which is presented separately from the population proportion, male family population scale, family population burden to investigate health investment lever under the different characteristics of peasant family population and to use statistical software for the single factor analysis of variance.

\section{The Empirical Analysis Results}

\section{Family Sex Ratios and Farmers Health Investment Level}

According to the proportion of male family population it can be divided into three types of male family proportion, less than 0.5 , equals 0.5 and exceeds 0.5 . As shown in table 1 , male in the larger scale peasant household spend 2670.06 Yuan on medical health; male in rural household spend on 2805.98 yuan medical health. Female and male proportion in equal spends 2598.09 Yuan on medical health. In comparison, the first is 135.92 Yuan less than the second, which means male health investment is less than female in poor area. The reason may be that women have higher sickened risk than men. For example, in poor rural of poor health condition and habits, women are much more likely to suffer from gynecological diseases. However, the results of variance analysis $(\mathrm{F}=0.38, \mathrm{P}=$ 0.6845) display male ratio change has no statistically significant influence on farmers health investment level.

Table 1 Different male proportion distribution and health investment level

\begin{tabular}{|l|c|c|}
\hline Family men ratio & sample constitute (\%) & $\begin{array}{l}\text { Average total income per } \\
\text { family(yuan) }\end{array}$ \\
\hline Less than 0.5 & 22.74 & 2805.98 \\
\hline Equal 0.5 & 34.26 & 2598.09 \\
\hline More than 0.5 & 43.00 & 2670.06 \\
\hline Total & 100.00 & 2581.28 \\
\hline
\end{tabular}

\section{Family Population Scale and Farmers Health Investment Level}

Sample in scale of average household is 4.3 people, the minimum is 1 , and the maximum is 12 . According to table 2, the four-people-household is the largest and the one-person-household is the smallest. The population scale in 4 or less is $55.60 \%, 5$ or less is $79.04 \%$, the scale of farmer households is mainly small.

Farmer's health investment level in different population scale basically enhances with the expansion of the household scale: 6 or more is the highest. This reflects people have healthy demand which similar to food demand and other life demand. This demand has the characteristics of rigidity; improve with the increase of population. However, from per household spending on medical health, two-people-household has the highest level of 922.93 Yuan, and four-people-household has the lowest of 549.87 Yuan. These differences may be caused by population structure. In the countryside, two-people-household is commonly old couple live separately with children, as older age and poor body, medical costs in higher levels. Four-people-household mainly consists of young couple and two children. As they are young, relatively good physical condition, medical cost is low. We use variance analysis to exam the outcome of health medical per year and per person. Result (per households: $\mathrm{F}=14.3, \mathrm{P}=0.0000$; per household per person: $\mathrm{F}=340.30, \mathrm{P}=0.0000$ ) displays that family population scale have statistically significant influence on health investment level . 
Table 2 Different population scale farmers distribution and their health investment level

\begin{tabular}{|l|l|c|c|}
\hline $\begin{array}{l}\text { Family } \\
\text { population scale }\end{array}$ & $\begin{array}{l}\text { sample } \\
\text { constitute } \\
(\%)\end{array}$ & $\begin{array}{l}\text { Average total } \\
\text { income per } \\
\text { family(\$) }\end{array}$ & $\begin{array}{l}\text { Average total income } \\
\text { per person }(\$)\end{array}$ \\
\hline 1people & 3.51 & 594.56 & 594.56 \\
\hline 2people & 10.48 & 1845.85 & 922.93 \\
\hline 3 people & 13.84 & 2016.94 & 672.31 \\
\hline 4 people & 27.78 & 2199.46 & 549.87 \\
\hline 5 people & 23.43 & 2877.48 & 575.50 \\
\hline $\begin{array}{l}\text { 6 people and } \\
\text { more }\end{array}$ & 20.96 & 3826.59 & 637.77 \\
\hline Total & 100.00 & 2581.28 & 600.30 \\
\hline
\end{tabular}

\section{Family Population Burden and Farmers Health Investment Level}

Investigation in population burden on economics mainly uses index of burden coefficient. It also says raising coefficient and refers to non-working age population in the overall population with the ratio of the working age population. The higher the ratio is, the heavier the burden is. It is a macro indicator, which shows that in the whole society or a national, regional, the population of nonworking labors has been support by each 100 working age population. Borrow this indicator connotation, we can analysis family population burden condition and get family population burden coefficient (the letter $r$ says), namely each family non-working age population with the ratio of working age population. Sample peasant households besides peasant households without labors, the largest family population burden coefficient is 4 , namely a labor burdens 4 non-labors, the smallest coefficient is 0 means all family members are labors. According to the different population burden, farmers family can divide into pure labor family $(\mathrm{r}=0)$, light burden family $(0<\mathrm{r} \leq 0.5)$, heavy burden family $(0.5<\mathrm{r} \leq 4)$. From table 3 we can see, light burden family have the biggest proportion, pure labor family is next, heavy burden family is minimum.

Accordingly, light burden family has highest level of health investment, higher than the second heavier burden family. This may be due to the light burden family have more rich labor resources, have advantage in economic sources and financing ability, which can better satisfy health investment requirements of family members, especially if the main labor sick, families can develop more economic advantages for its treatment. Although the heavy burden family have bigger need for health, the need is restricted by their own economic sources, health needs of family members are not fully satisfied. Pure labor family health investment level is minimum, the main reason is that pure labor family have no children and elderly people, their health condition is generally good, need of health is relatively small, so health investment level is low. The results of variance analysis $(F=5.97$, $\mathrm{P}=0.0026$ ) also shows its statistical significant.

Table 3 Different family population burden distribution and health investment level

\begin{tabular}{|l|c|c|}
\hline $\begin{array}{l}\text { Domestic population } \\
\text { burden }\end{array}$ & sample constitute (\%) & $\begin{array}{l}\text { Average total income per } \\
\text { family(Yuan) }\end{array}$ \\
\hline Pure labor family & 36.46 & 2169.37 \\
\hline Light burden family & 39.43 & 3218.27 \\
\hline Heavy burden family & 24.11 & 2499.77 \\
\hline \multicolumn{1}{|c|}{ Total } & 100.00 & 2581.28 \\
\hline
\end{tabular}




\section{Conclusions and Suggestion}

Through gender differences of family health investment comparative analysis, we can see that in poor rural areas, a women's health investment is relative higher than men's , which shows that women's society health risks are rather higher than men's. But the results of variance analysis showed no statistical significance, so the influence from gender constitution on the family health investment still needs further research.

Family population scale has significant effects on health investment level, which is reflected in two aspects: one is that the household medical care spending changes because of the population scale constantly expanded, and it means health investment has steel needs. The other one is that per household medical care spending show opposite trend, namely fewer people but more investment and more people but less investment, which be seen in reality that the investment from two-peoplehousehold is the highest and that from four-people-household is the lowest. The situation may be due to the age structure and physical condition of the family members.

Family population burden also has statistical influence on farmers' health investment level. Light burden farmers' health investment level is the highest, probably for light burden families with multiple income have more labor resources, and have some advantage in economic ability, which can better satisfy health investment requirements of family members. Pure labor family health investment level is minimum, because pure labor family have no children and elderly people, their health condition is generally good, need of health is relatively small.

The study helps design and perfects rural medical security policy. The government's health care program provides rural social members health insurance, which emphasizes on improving rural health condition and health habits, and enhances rural population to reduce health risk, especially raises rural women's health care consciousness. The lighter burden family should have more investment on health. This provides reference for rural health care policy design which aims at the farmers of different features.The government should strengthen health risk awareness propaganda and prevention work in rural especially poor rural areas, while it should provide every peasant household with the basic medical security, and actively encourage conditional farmers to buy commercial insurance, which can make less the impact of the health risks.

\section{Comments}

The non-working age population mainly includes children of $0 \sim 14$ years old and elderly aged 65 years old and above; working age population refers to labors of $15 \sim 64$ years old.

\section{Acknowledgement}

This research was financially supported by the grants from Hubei Provincial Collaborative Innovation Center of Agricultural E-Commerce (under Construction) (Wuhan Donghu university research [2015] No. 11 Document), "Under the Background of the Internet, College Students Entrepreneurial Enterprise E-commerce Ability Research”.

\section{References}

[1] Hongbo CHEN, Keli Wang,Discussion health investment and economic development,J.Chinese health resources. 2007 (1). (In Chinese)

[2] IMAI K S,GAIHA R,Does Agricultural Growth Reduce Inequality and Poverty in Developing Countries? R.Discussion Paper.2015 (4).

[3] BHATTACHARYYAS,The Historical Origins of Poverty in Developing Countries,R.Mpra Paper, 2016.

[4] Fang HE, Hui He, Jingming LI, How to deal with the social security of family structure during the transformation time,J. Law and social. 2009 (2). (In Chinese) 
[5] ZHU N,LUO X,The Impact of Migration on Rural Poverty and Inequality:A Case Study in China,J. Agricultural Economic.2014,41 (2):191-204. (In Chinese)

[6] Xia MENG, The contemporary Chinese social population structure and family structure,J. Hubei social science. 2009 (5). (In Chinese) 